\title{
NEUTROPHIL TO LYMPHOCYTE RATIO AND THROMBOCYTE TO LYMPHOCYTE RATIO, NEW BIOCHEMICAL PARAMETERS IN ACUTE PANCREATITIS
}

\author{
Georgiana Cătălina Crișu1,2, Valeriu Atanasiu², Flavius Ștefan Marin³, Vasile Daniel Balaban², \\ Laura Găman², Irina Stoian², Mariana Jinga ${ }^{2,3}$ \\ ${ }^{1}$ County Emergency Hospital of Ploiești, Romania \\ "Carol Davila" University of Medicine and Pharmacy, Bucharest, Romania \\ "Dr Carol Davila" Central Emergency University Military Hospital, Bucharest, Romania \\ Corresponding author: \\ Georgiana Cătălina Crișu \\ e-mail:georgi_robu@yahoo.com
}

\begin{abstract}
Background. Acute pancreatitis represents an inflammatory disease with different grades of severity, ranging from mild to severe presentation. In current practice there are a lot of biomarkers used in diagnosis and prognosis of pancreatitis.
\end{abstract}

The aim of this study was to evaluate de differences between a group with acute pancreatitis and a group of healthy people regarding the neutrophil to lymphocyte ratio (NLR), thrombocyte to lymphocyte ratio (TLR), as these two could help in the evaluation of prognosis and severity of acute pancreatitis.

Method. The study had two groups: group A, included 100 patients with acute pancreatitis and group $B$ - 30 healthy people.

Results. In the group $A$ there were $65 \%$ male and $35 \%$ female with a mean age of $58.07 \pm 15.10$ years, in the group $B$ there were $50 \%$ male and $50 \%$ female with a mean age of $48.06 \pm 15.47$ years. The majority of the people included in both groups were from the urban provenience. We obtained an important difference between group $A$ and group $B$ regarding the neutrophil to lymphocyte ratio and thrombocyte to lymphocyte ratio with an important statistical significance $(p<0.001)$.

Conclusion. Neutrophil to lymphocyte ratio and thrombocyte to lymphocyte ratio could be promising biochemical parameters in diagnosis and prognosis of acute pancreatitis.

Keywords: acute pancreatitis, neutrophil to lymphocyte ratio, thrombocyte to lymphocyte ratio. 


\section{INTERNAL}

\section{Original papers}

\section{Rezumat}

Introducere. Pancreatita acută reprezintă o condiţie inflamatorie, având diferite grade de severitate, variind de la uşoară la severă. În practica curentă există o gamă variată de biomarkeri folosiți în diagnosticul și prognosticul pancreatitei acute.

Scopul studiului nostru este evaluarea importanţei raporturilor neutrofile /limfocite, trombocite/limfocite la pacienţii cu pancreatită acută versus subiecţii sănătoşi.

Materiale şi metodă. Pacienții incluși în studiu au fost împărţiți în 2 loturi: lotul A ce a inclus 100 de pacienţi cu pancreatită acută şi lotul B ce a inclus 30 de subiecţi sănătoşi.

Rezultate. În lotul A au predominat pacienţii de sex masculin - 65\%, iar vârsta medie a fost de 58,07 $\pm 15,10$ ani, în schimb în lotul B distribuţia pe sexe a fost similară, cu o vârstă medie de 48,06 15,47 ani. Atât subiecţii din lotul A, cât şi subiecţii din lotul B au provenit în marea majoritate din mediul urban. Am obţinut o diferenţa semnificativă statistic privind raporturile NLR și TLR pentru lotul cu pacienţi cu pancreatită acută faţă de subiecţii sănătoşi $(p<0,001)$.

Concluzii. Raporturile neutrofile/limfocite, precum şi trombocite/limfocite pot fi considerate parametri biochimici promiţători în diagnosticul şi prognosticul pancreatitei acute.

Cuvinte cheie: pancreatita acută, raport neutrofile/limfocite, raport trombocite/limfocite.

\section{Background}

Acute pancreatitis represents an inflammatory disease with different grades of severity, ranging from mild to severe presentation. For a good outcome it is necessary to early identify the severity of the disease and to apply a correct management for the high risk patients ${ }^{(1)}$.

Acute pancreatitis represents one of the most common reasons for gastroenterological hospitalization and it is associated with abdominal pain and high level of pancreatic enzymes ${ }^{(2)}$. The most common causes are gallstones and alcohol consumption.

The classification of severity of acute pancreatitis can be defined by the presence of complications that are systemic, local or both. Systemic complications include any failure of an organ (respiratory, cardiovascular or renal) or exacerbation of any preexisting condition. Local complications include peripancreatic fluid 
collection, pseudocysts, pancreatic or peripancreatic necrosis (sterile or infected $)^{(3)}$.

To establish the severity of acute pancreatitis it is necessary to take into account clinical symptoms and signs, biochemical parameters and imagistic signs. Several scoring systems have been developed, including clinic, laboratory and radiographic findings in different combinations: APACHE, Balthazar score, BISAP score. There isn't any earlier score system for predicting the severity of the disease ${ }^{(4,5,6)}$. That's why in the recent years many clinicians have been tried to develop new scoring system using daily biochemical parameters, such as neutrophil to Iymphocyte ratio, thrombocyte to lymphocyte ratio, red cell distribution width $(\mathrm{RDW})^{(7,8,9,10)}$.

The aim of the study was to evaluate de difference between a group with acute pancreatitis and a group of healthy people regarding the neutrophil to lymphocyte ratio, thrombocyte to lymphocyte ratio, as these two could help in prognosis of severity of the acute pancreatitis.

\section{Method}

Our study included patients divided into two groups: group A - 100 patients admitted in the department of gastroenterology with acute pancreatitis and group B - 30 healthy people who came to hospital for routine evaluation.

Laboratory tests (including the complete blood count, total cholesterol, transaminases, bilirubin, alkaline phosphatase levels) were performed to all the patients after a clinical examination.

The results were presented as meant standard deviation for numeric variables and as absolute numbers and percentage for categorical variables, using Shapiro Wilk test. Statistical analysis was performed by using $\mathrm{R}$ programming soft, version 3.5.3. (2019-03-11) Copyright (C) 2019. The statistical significance was considered for $a p$ value $<0.05$

\section{Results}

The baseline characteristics of the study patients are presented in Table 1 . The mean age for the group A was $58.07 \pm 15.10$ years with male predominance $(65 \%$ of the patients); for group $B$ the mean age was $48.06 \pm 15.47$ years with an equal sex predominance.

The majority patients from the both group were from the urban environment.

We represent a difference between these two groups regarding the values of number of leukocytes, thrombocytes, haemoglobin, cholesterol, triglycerides, transaminases, bilirubin, alkaline phosphatase (see Table 2). There was a significant difference between group $A$ and group $B$ regarding the granulocytes to lymphocytes ratio, $9.78 \pm 11.58$ in group $A$ versus $2.34 \pm 1.10$ in group $B(p<0.0001)$ (see Figure 1$)$.

We also have compared the group with patients diagnosed with acute pancreatic versus the healthy group regarding the thrombocytes to lymphocytes ratio and we have got a significance difference of $243.09 \pm 230.60$ in group $A$ versus $138.78 \pm 51.94$ in group $B$ (with a $p<0.0001$ ) (Table 3).

\section{Discussions}

It is very difficult to obtain a simple, inexpensive, widely applicable in daily clinical practice prognostic score for acute pancreatitis. The current guidelines don't 


\section{Original papers}

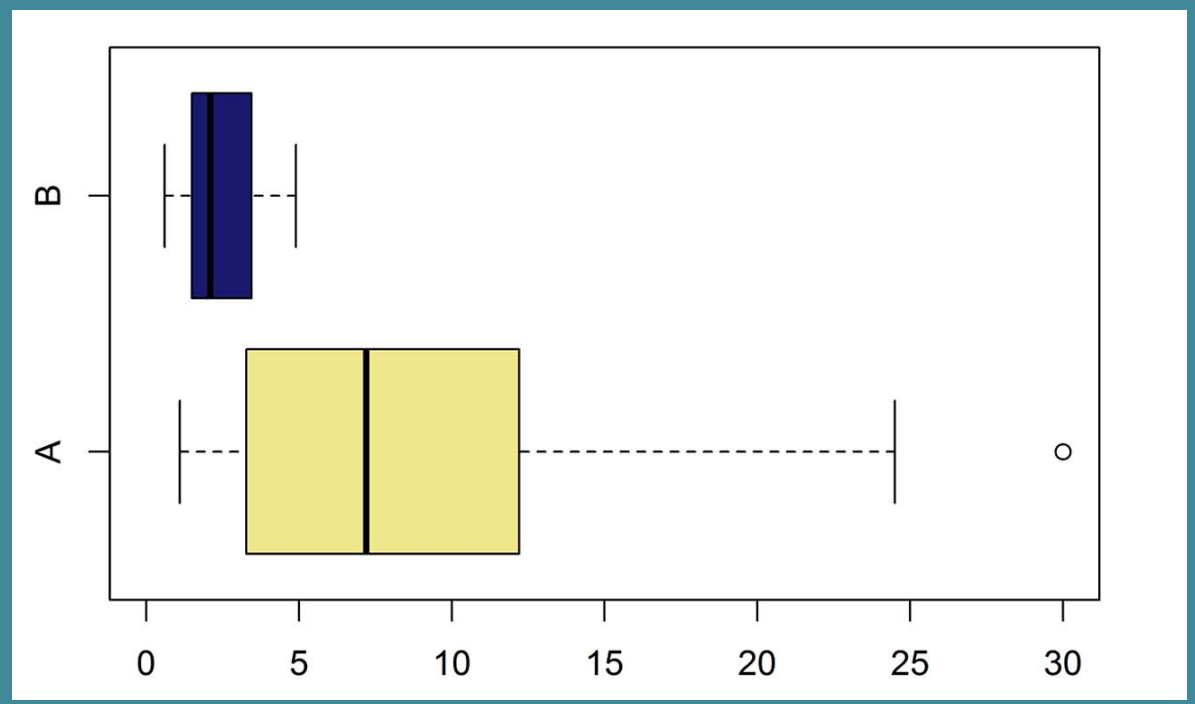

Figure 1. Granulocytes to lymphocytes ratio in group A and B

\begin{tabular}{|l|l|l|}
\hline Patient characteristics & group A (No = 100) & group B (No = 30) \\
\hline Age - Mean \pm S.D & $58.07 \pm 15.10$ & $48.06 \pm 15.47$ \\
\hline Sex M - No. (\%) & $65(65.00)$ & $15(50.00)$ \\
F - No. (\%) & $35(35.00)$ & $15(50.00)$ \\
\hline Residency City - No. (\%) & $75(75.00)$ & $23(76.67)$ \\
Rural - No. (\%) & $25(25.00)$ & $7(33.33)$ \\
\hline
\end{tabular}

Table 1. Baseline characteristics of the study groups 


\begin{tabular}{|l|l|l|}
\hline Leukocytes - Mean (IQR) & $10855.00(7600.00)$ & $6720.00(2450.00)$ \\
\hline $\begin{array}{l}\text { Trombocytes - Mean } \pm \\
\text { S.D }\end{array}$ & $268450 \pm 114454$ & $257366 \pm 51717$ \\
\hline $\begin{array}{l}\text { Lymphocytes - Mean } \pm \\
\text { S.D }\end{array}$ & $1355.00 \pm 581.33$ & $2066.56 \pm 724.38$ \\
\hline $\begin{array}{l}\text { Granulocytes - Mean } \pm \\
\text { S.D }\end{array}$ & $9481.70 \pm 4995.70$ & $4473.00 \pm 1690.53$ \\
\hline Basophil - Mean (IQR) & $65.00(205.00)$ & $20.00(40.00)$ \\
\hline Monocytes - Mean (IQR) & $800.00(580.00)$ & $500.00(240.00)$ \\
\hline RDW - Mean \pm S.D & $34.92 \pm 15.36$ & $32.87 \pm 13.27$ \\
\hline Hb - Mean \pm S.D & $13.83 \pm 2.18$ & $14.21 \pm 1.60$ \\
\hline Cholesterol - Mean \pm S.D & $181.44 \pm 73.38$ & $201.82 \pm 61.53$ \\
\hline TGL - Mean (IQR) & $100.50(51.00)$ & $114.00(76.00)$ \\
\hline & & $20.00(9.00)$ \\
\hline AST - Mean (IQR) & $40.50(85.00)$ & $21.50(7.50)$ \\
\hline ALT - Mean (IQR) & $34.00(112.00)$ & $0.64 \pm 0.27$ \\
\hline TB - Mean \pm S.D & $1.51 \pm 1.49$ & $73.00(32.00)$ \\
\hline DB - Mean \pm S.D & $0.62 \pm 0.94$ & 0.12 \\
\hline AF - Mean (IQR) & $92.00(97.00)$ & $148.50(395.00)$ \\
\hline GGT - Mean (IQR) & & $200)$ \\
\hline
\end{tabular}

Table 2. Laboratory parameters in the group $A$ and $B$

\begin{tabular}{|l|l|l|}
\hline Raport T/L & Lot A & Lot B \\
\hline Medie \pm D.S & $243.09 \pm 230.60$ & $138.78 \pm 51.94 *$ \\
\hline Median (IQR) & $197.10(131.00)$ & $121.40(78.30)$ \\
\hline Min - Max & $53.10-2194.00$ & $65.60-254.00$ \\
\hline
\end{tabular}

Table 3. Thrombocytes to lymphocytes ratio in the study groups $(* p<0.0001)$ 




Original papers

mention which is the best prognostic score for the assessment of the severity of acute pancreatitis.

Neutrophil to lymphocyte ratio was first reported as parameter in systemic inflammation by Zahorec et al in critically ill patients and after that has been studied in malignant and nonmalignant pathologies ${ }^{(11,12}$, ${ }^{13,14)}$. Yuchen Wang et al showed in a study that neutrophil to lymphocyte ratio can be used as a prognostic value in patients with hypertriglyceridemia induced acute pancreatitis ${ }^{(15)}$.

Robert M. O'Connel et al evidenced in a retrospective study that neutrophil to lymphocyte ratio could have a potential predictive value on admission in patients with acute pancreatitis ${ }^{(16)}$. In our study, patients with acute pancreatitis were found to have higher values not only for neutrophil to lymphocyte ratio but also for thrombocyte to lymphocyte ratio comparing to control.

\section{Conclusions}

The new biochemical markers such as neutrophil to lymphocyte ratio and thrombocyte to lymphocyte ratio might represent better tools in stratification of patients with acute pancreatitis. Our study has noticed the importance of these two biochemical parameters in patients with acute pancreatitis compared to healthy people.

\section{References}

1. Lempinen M., Puolakkainen P., Kemppainen E.Clinical value of severity markers in acute pancreatitis. Scandinavian Journal of Surgery, 2005, 94:118123

2. Forsmark Chris E., Swaroop Santhi Vege, Wilcox Mel C., Acute pancreatitis. The New England Journal of Medicine, 2016;375:1972-81.

3. Banks PA, Bollen TL, Dervenis C, Gooszen HG, Johnson CD, Sarr MG et al. Classification of acute pancreatitis - 2012: revision of the Atlanta classification and definitions by international consensus. Gut 2013; 62: 102-11

4. Guo Q, Li M, Chen Y, Hu W., Determinant -based classification and revision of the Atlanta classification, which one should we choose to categorize acute pancreatitis? Pancreatology.2015;4:331-336.

5. Mounzer R, Langmead $C J$, Wu BU, Evans AC, Bishehsari F, Muddana $V$ et al., Comparison of existing clinical scoring systems to predict persistent organ failure in patients with acute pancreatitis. Gastroenterology 2012; 142: 1476-82.

6. Mentula $P$, Kylänpää ML, Kemppainen E, Jansson SE, Sarna S, Puolakkainen P, Haapiainen R, Repo H: Early prediction of organ failure by combined markers in patients with acute pancreatitis. BrJ Surg 2005;92:6875

7. Schutte K, Malfertheiner P. Markers for predicting severity and progression of acute pancreatitis. Best Pract Res Clin Gastroenterol 2008;22:7590

8. RobertJH, Frossard JL, Mermillod B, Soravia C, Mensi $N$, Roth $M$ et al. Early prediction of acute pancreatitis: prospective study comparing computed tomography scans, Ranson, Glascow, Acute Physiology and Chronic Health Evaluation II scores, and various serum markers. World J Surg 2002;26:61219.

9. Al-Bahrani AZ, Ammori BJ. Clinical laboratory assessment of acute pancreatitis. Clin Chim Acta 2005;362:2648.

10. Carroll JK, Herrick B, Gipson T, Lee SP. Acute pancreatitis: diagnosis, prognosis, and treatment. Am Fam Phys 2007;75: 151320. 
11. Zahorec R.Ratio of neutrophil to lymphocyte countsrapid and simple parameter of systemic inflammation and stress in critically ill .Bratisl Lek Listy 2001; 102 (1), 5-14.

12. Sharaiha RZ, Halazun KJ, Mirza F, Port JL, Lee $P C$, Neugut Al et al. Elevated preoperative neutrophil:lymphocyte ratio as a predictor postoperative disease recurrence in esophageal cancer. Ann Surg Oncol $2011 ; 18$ (12):3362-9.

13. Stotz M, Gerger A, Eisner F, Szkandera J, Loibner $H$, Ress $A L$, et al. Increased neutrophil-lymphocyte ratio is a poor prognostic factor in patients with primary operable and inoperable pancreatic cancer.British Journal of Cancer ,2013;109:416421

14. Jeon J T, Park Young Ji .Clinical significance of the neutrophil-lymphocyte ratio as an early predictive marker for adverse outcomes in patients with acute pancreatitis. World J Gastroenterol. Jun 7, 2017; 23(21): 3883-3889

15. Wang $Y$, Fuentes $H E$, Attar BM, Jaiswal P, Demetria $M$ et al. Evaluation of the prognostic value of neutrophil to lymphocyte ratio in patients with hypertriglyceridemiainduced acute pancreatitis, Pancreatology, 2017;17(6):893-897.

16. O'Connell RM, Bolland MR, O'Driscoll J, Salih A, Arumugasamy M,Walsh TN. Red Cell Distribution Width And Neutrophil To Lymphocyte Ratio As Predictors Of Outcomes In Acute Pancreatitis: A Retrospective Cohort Study. International Journal of Surgery ,2018,55:124127 